\title{
Evaluation of Quality Raw Cashew (Anacardium occidentale L.) Nuts from Major Cashew Producing Regions of Senegal
}

\author{
Fatou Dieng, ", Daouda Ngom², Djiby Dia ${ }^{3}$, Mouhamed Rassoul Sy ${ }^{3}$, Seydou Ndiaye ${ }^{1}$, \\ Mohamadou Dieye ${ }^{3}$ \\ ${ }^{1}$ Department of Agroforestry, Assane Seck University, Diabir, Ziguinchor, Senegal \\ ${ }^{2}$ Laboratory of Plant Ecology, Faculty of Science and Technology, Cheikh Anta Diop University, Dakar, Senegal \\ ${ }^{3}$ Bureau d'Analyses Macro-Economiques, Institut Senegalais de Recherches Agricoles, Bel Air Route des Hydrocarbures, Dakar, Senegal \\ Email address: \\ fadieng83@yahoo.fr(F. Dieng),ngom_daouda@yahoo.fr(D. Ngom), djiby.dia@isra.sn(D. Dia), syrassoul@gmail.com(M. R. Sy), \\ s.ndiaye2860@zig.univ.sn (S. Ndiaye), dieyemohamadou@gmail.com(M. Dieye) \\ ${ }^{*}$ Corresponding author
}

\section{To cite this article:}

Fatou Dieng, Daouda Ngom, Djiby Dia, Mouhamed Rassoul Sy, Seydou Ndiaye, Mohamadou Dieye. Evaluation of Quality Raw Cashew (Anacardium occidentale L.) Nuts from Major Cashew Producing Regions of Senegal. American Journal of Agriculture and Forestry. Vol. 8, No. 5, 2020, pp. 190-197. doi: 10.11648/j.ajaf.20200805.12

Received: July 7, 2020; Accepted: July 24, 2020; Published: September 24, 2020

\begin{abstract}
Cashew nuts are one of the main cash crops that compete strongly with groundnuts and cotton in Senegal. However, there is no clear scientific evidence to confirm or refute this argument, so this fact is not widely known. This raises a knowledge gap and justifies the need to analyze the nut quality. Raw cashew nut qualities were evaluated using the Out-turn and Principal Component Analysis (PCA) method. Twelve samples of nuts were taken from producers, processors, buyers, and exporters in the four production regions in Senegal. The main quality criteria studied are: Kernel Output Ratio (KOR), Defect Rate (DR), Kernel Yield (KY) and moisture content. The results showed that the highest KOR was recorded in the nuts sourced from Ziguinchor region (45 $\pm 6 \mathrm{lbs})$ while the lowest was noted in nuts from Fatick region $(38 \pm 9)$. The KORs for the Kolda (42 $\pm 8 \mathrm{lbs})$ and Sedhiou (42 $\pm 5 \mathrm{lbs})$ regions are similar. The tests indicated a good quality of Senegalese cashew nuts. The average over the whole sample is $42 \pm 9 \mathrm{lbs}$ per $80 \mathrm{~kg}$ lot compared to international standards which vary from 40 to $50 \mathrm{lbs}$ per $80 \mathrm{~kg}$ lot. Kernel yield is $24 \%$ compared to $22 \%$ applied by the largest manufacturers in Asian and South American countries. Nut Count is 193 \pm 40 grains per kilogram compared to 190 grains per kilogram applied by some industrial exporters. The average moisture content is $8 \%$, confirming the international standards. The political implication of these results is that in addition to consolidating the quality of the production, it is essential to emphasize the valorization of the kernel through processing in order to create more added value, employment, and wealth for Senegal.
\end{abstract}

Keywords: Raw, Cashew Nut, Production, Kernel, Quality, KOR, Senegal

\section{Introduction}

Cashew nuts are now positioned as one of the main cash crops [13], competing strongly with groundnuts and cotton in Senegal. It has enabled a growing number of households to have additional income during the dry season from production activities but also from artisanal processing, especially for women [25].

Out of a world production of 2,200,000 tonnes [24]. Senegal accounts for only $0.8 \%$. The country exports the bulk of its production in the form of raw nuts to India, China, and
Vietnam and annually processes only $2.92 \%$ of its production in-country, i.e. 500 tonnes of nuts [25]. Cashew kernels obtained after shelling are a prestigious product for countries such as India, United States, European Union, China, United Arab Emirates and Australia.

The value chain is carried by thousands of village producers who supply large urban traders, local and foreign exporters through a system of village shops, weekly markets and, above all, collectors who travel through the villages to collect the 
nuts. The system also takes into account the cross-border cashew nut traffic along the border with Guinea Bissau, thereby greatly increasing the availability of nuts [12].

The quality of the nuts is an important factor in the marketing of the product [12]. Buyers request a certain quality of nuts with the corollary of a good quality of almonds [23]. The potential buyers who demand this quality control in Senegal are the Indians and the Chinese. Thus, good control of the quality of the nuts makes it possible to better negotiate the price. The actors involved in this quality are the producers, the collectors-buyers, and the processors. According to the study conducted by USAID/SAGIC [30], Fatick region offers the best nut quality, followed by Ziguinchor and Kolda. The introduction of the first varieties improved by the Senegalese Cashew Nut Shelling Project (PASA) in the Fatick region (1980-1990) as well as the intervention of the PFRK (Projet Forestier Rural de Kolda) and PAEFK (Projet d'Appui à l'Entrepreunariat Forestier de Kolda) projects in Casamance contributed to this quality [29].

Some studies have been carried out in Senegal on cashew nuts $[6,9,19,27,28]$ but none have focused on the quality of nuts in the major producing areas. Hence, the present study was undertaken to determine and document the quality of the cashew nuts in the large production areas, and, more specifically, to determine the nut count, kernel yield, defect rate, and the KOR (Kernel Output Ratio) per production area.

\section{Material and Methods}

\subsection{Study Area}

The study was conducted in the two main cashew nut-producing, agro-ecological zones in Senegal (Figure 1).

These are Casamance (regions of Kolda $\left(12^{\circ} 53^{\prime} 00^{\prime \prime} \mathrm{N}\right.$, $\left.14^{\circ} 57^{\prime} 00^{\prime \prime} \mathrm{W}\right)$, Sedhiou $\left(12^{\circ} 42^{\prime} 29^{\prime \prime} \mathrm{N}, 15^{\circ} 33^{\prime} 25^{\prime \prime} \mathrm{W}\right)$, and Ziguinchor $\left(12^{\circ} 33^{\prime} 40^{\prime \prime} \mathrm{N}, 1^{\circ} 17^{\prime} 00^{\prime \prime} \mathrm{W}\right)$ and Sine-Saloum (region of Fatick 14⒈ $19^{\prime} 00^{\prime \prime} \mathrm{N}, 16^{\circ} 25^{\prime} 00^{\prime \prime} \mathrm{W}$ ) [26].

These regions are located in the southern and central part of the country. The average annual rainfall ranges from 700 to more than $1300 \mathrm{~mm}$. Casamance has a Sudano-Guinean climate while the Fatick region is characterized by a semi-arid tropical climate ([2]. The choice of the study area is justified by the fact that $90 \%$ of cashew nut production is concentrated in this area [25].

Casamance benefits from significant natural resources that offer development opportunities for the agricultural and agroforestry sectors. It is also an area that was once heavily landlocked and is being rebuilt following an irredentist conflict lasting more than three decades. These specificities deserve special attention.

As for the Fatick region, it highly valued the intervention of PASA and the Cashew Husk Shelling Company of Senegal (SODENAS) in the 1980s. "PASA and SODENAS projects have been very beneficial for the region in terms of providing livelihood for the residents.

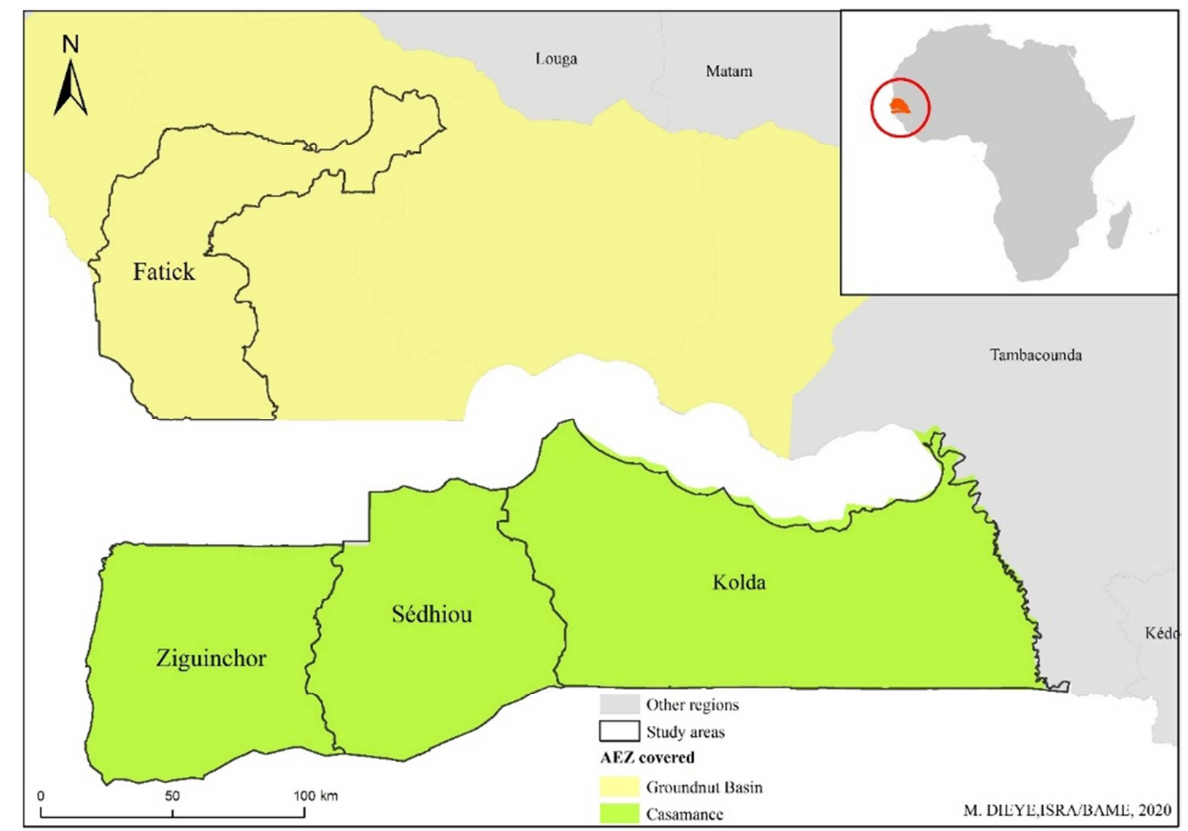

Figure 1. Localization of the major cashew producing regions in Senegal Study area.

\subsection{Data and Methods}

\subsubsection{Sample Collection and Preparation}

Twelve composite samples of Western Anacardium nuts were sourced from Indian producers, processors, buyers, and exporters in the four production regions in Senegal, based on three samples/region (each sample corresponds to $1 \mathrm{~kg}$, repeated three times for each region). The main quality criteria were investigated:

\subsubsection{Quality Evaluation}

\section{i. Moisture content}

The moisture content was measured using the moisture meter type MS-G suitable for cashew nuts. The instrument is immersed in the sample. The results are obtained by direct reading on the display: percent (\%) normal humidity $<100 \mathrm{C}$ 
and percent (\%) high humidity $>100 \mathrm{C}$.

\section{ii. Nut Count}

The nut count, which represents the number of nuts per kilogram, is expressed in nuts $/ \mathrm{kg}$. It varies generally between 150 and 240 nuts $/ \mathrm{kg}$. The smaller the number, the larger the nuts. To obtain the kernel value, the number of nuts counted in the sample was divided by the weight of the sample (Figure 2).
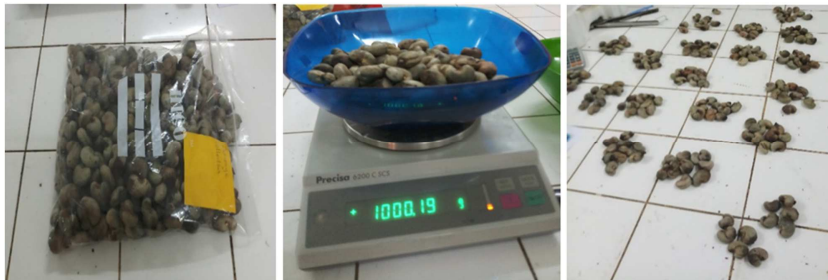

Figure 2. (a) Sample (b) Sample mesure (c) Nut count processing

$$
\text { Nut Count }=(\mathrm{N}) / \mathrm{P} 1
$$

where $\mathrm{P} 1=$ the weight of the sample and $\mathrm{N}=$ the number of nuts in the sample. For the interpretation of the graining values, we used the African Cashew Initiative's graining appreciation table (Table 1).

Table 1. Correspondence grain/quality of cashew nuts.

\begin{tabular}{ll}
\hline Number of nuts per kg & Quality assessment \\
\hline Under 180 & Excellent \\
{$[180-190[$} & Very good \\
{$[190-200[$} & Good \\
{$[200-210[$} & Medium \\
{$[210-220[$} & Very average \\
{$[220-230]$} & Just acceptable \\
Beyond 230 & Bad \\
\hline
\end{tabular}

Source: ACA, 2011.

\section{iii. Defect Rate}

The Defect Rate measures the quantity of nuts in the sample with a defect. To determine the defect rate, all nuts in the sample were cut lengthwise with the hornbill so that two halves with or without defects were obtained. The African Cashew Alliance [1] has classified the nuts into three classes based on the quality of the kernels making it possible to identify those with defects. The blue class represents nuts where only $50 \%$ of the nut is accepted and is composed of immature and pricked nuts (Figure 3).
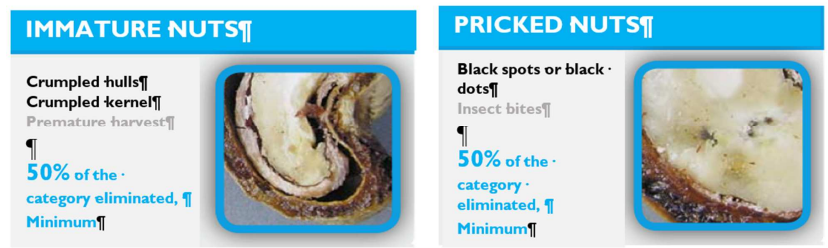

Photo credit: ACA, 2011.

Figure 3. Blue Class Nuts.

The red class represents nuts where $100 \%$ of the nut rejected and is composed of stunted nuts, empty nuts, mottled nuts, moldy nuts, and buttered nuts (Figure 4).

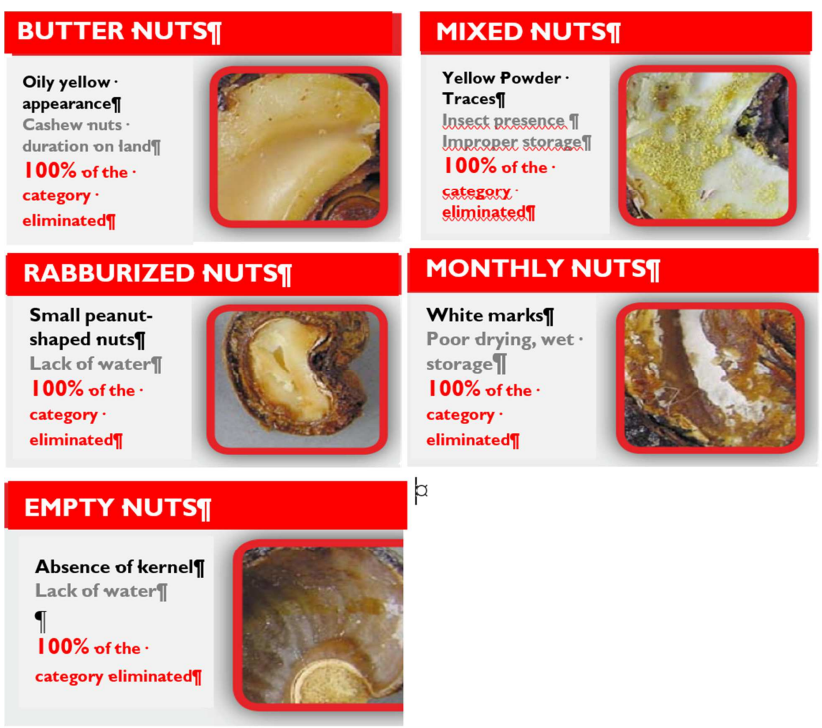

Photo credit: ACA, 2011.

Figure 4. Red class nuts

Nuts without defects are classified in the green class (Figure 5). To calculate the defect rate, the following formula was applied with the data obtained by weighing the nuts andhulls of the blue and red categories.

The defect rate is expressed as a percentage $=(\mathrm{P} 3+\mathrm{P} 5) / \mathrm{P} 1 \mathrm{X} 100(2)$

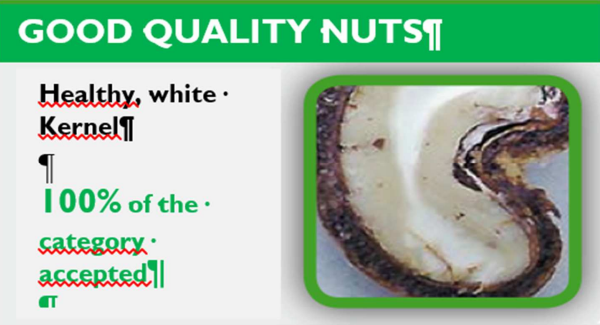

Photo credit: ACA, 2011.

Figure 5. Green class nuts.

$\mathrm{P} 1=$ total weight of the nut sample;

$\mathrm{P} 5=$ weight of the $100 \%$ rejected nuts (red class);

P3 $=$ weight of $50 \%$ rejected nuts (blue class).

In general, a sample of nuts with a defect rate greater than $24 \%$ is rejected. This calculation is faster and simpler than the Out Turn or the kernel yield calculations, and it gives a first indication of the nuts' quality.

iv. Kernel Yield

The KOR, or kernel yield, is an important parameter that allows the producer or exporter to control the quality of the nuts. It represents the quantity in British pounds (lb) of good kernel that can be included in an $80 \mathrm{~kg}$ bag of nuts after shelling. It is expressed in $1 \mathrm{bs} / 80 \mathrm{~kg}$ bag [26].

For the calculation, the Kernel yield must first be calculated by applying the formulas below with the data obtained from the weighing.

Either:

- P1 is the total weight of the nut sample;

- P4 is the total weight obtained of the Kernel + skins of the 
nuts rejected at $50 \%$;

- P2 is the total weight obtained of the kernel + skins of healthy nuts.

$$
\mathrm{KY}(\text { Kernel Yield })=(\mathrm{P} 2+\mathrm{P} 4 / 2) / \mathrm{P} 1 \mathrm{X} 100
$$

Thus, the yield KY becomes the out-turn or KOR by performing the following conversion:

$$
\mathrm{KOR}=\mathrm{KY} / 100 \times 80 \times 1 / 0.45359
$$

\section{v. Principal Component Analysis (PCA)}

As part of this study, the PCA was conducted to determine a trend in the comparison of nut quality between producing regions and to detect similarities between individuals. PCA is a method to summarize the variability of the parameters collected and to position the individuals in relation to the variables $[8,18]$. Table 2 presents the variables used for the CPA and their description.

Table 2. CPA Variables.

\begin{tabular}{ll}
\hline Variables & Description \\
\hline KOR & Kernel Output Ratio \\
NC & Number of nuts per kilogram (Nut Count) \\
Humidity & Amount of water vapour contained in the nuts \\
DR & Quantity of nuts with a defect (Defect Rate) \\
KY & Quantity obtained after shelling (Kernel yield) \\
UK & Useful Kernel \\
Log_ind & Kolda, Sedhiou, Ziguinchor Fatick) \\
\hline
\end{tabular}

\section{Results}

\subsection{Analysis of Quality Raws by Region}

\subsubsection{Quality Test for the Fatick Region}

The results from Fatick (Table 3) showed that the average kernel weight was $145 \pm 16.1$ nuts/kg and the defect rate is $13 \%$. Kernel yield is $22 \%$. The region has nuts with an average KOR of $38 \pm 9 \mathrm{lbs}$ with a maximum of 45 . Humidity varied between 7 and $8 \%$. The combined count test and yield test show excellent nut quality. However, the link analysis showed that growers have lower quality nuts due to poor storage conditions after harvest. Better quality nuts are obtained at the processor level (KOR is equal to $45 \mathrm{lbs}$ and $\mathrm{KY}$ is equal to $25 \%$ ).

Table 3. Assessment of nut quality for Fatick region.

\begin{tabular}{llllll}
\hline & NC & DR & UK & KY & KOR \\
\hline Sample 1 & 128 & 19 & 163 & $16,3 \%$ & 29 \\
Sample 2 & 160 & 9 & 254 & $25,4 \%$ & 45 \\
Sample 3 & 147 & 9 & 236 & $23,6 \%$ & 42 \\
Average & 145 & 13 & 218 & $21,8 \%$ & 38 \\
Standard deviation & 16.1 & - & - & - & 9 \\
\hline
\end{tabular}

\subsubsection{Quality Test for the Kolda Region}

The average grading is $211 \pm 32$ nuts $/ \mathrm{kg}$, the defect and moisture content are $11 \%$ and $8.4 \%$, respectively. Kernel yield is $24 \%$ with a KOR of $42 \pm 8$ Ibs (Table 4 ). The combined count test and yield test show a very average quality of the nuts. The number of nuts per kilogram for this region is still high. Contrary to the Fatick region, the best nuts are obtained from the growers (with a KOR of $49 \mathrm{Ibs}$ and a KY of 27\%).

Table 4. Assessment of nut quality for Kolda region.

\begin{tabular}{llllll}
\hline & NC & DR & UK & KY & KOR \\
\hline Sample 1 & 243 & 12 & 280 & $27,4 \%$ & 49 \\
Sample 2 & 180 & 10 & 187 & $18,7 \%$ & 33 \\
Sample 3 & 211 & 12 & 246 & $24,6 \%$ & 43 \\
Average & 211 & 11 & 238 & $23,8 \%$ & 42 \\
Standard deviation & 32 & - & - & - & 8 \\
\hline
\end{tabular}

\subsubsection{Quality Test for the Sedhiou Region}

The average nut count is $187( \pm 18)$ nuts $/ \mathrm{kg}$, the defect rate is $10 \%$. Kernel yield is $24 \%$ with a KOR of $42 \pm 5 \mathrm{lbs}$ (Table 5). The average moisture content is $8.4 \%$.

The combined count test and yield test showed a good quality of the nuts from Sedhiou especially in the Balantacounda area. The link analysis showed similar results with Fatick, and the best nuts are obtained with the processors (with a KOR of $48 \mathrm{lbs}$ and a KY of $27 \%$ ).

Table 5. Assessment of nut quality for Sedhiou region.

\begin{tabular}{llllll}
\hline & NC & DR & UK & KY & KOR \\
\hline Sample 1 & 198 & 8 & 280 & $27,3 \%$ & 48 \\
Sample 2 & 166 & 10 & 187 & $22,6 \%$ & 40 \\
Sample 3 & 196 & 11 & 246 & $21,9 \%$ & 39 \\
Average & 187 & 10 & 238 & $23,9 \%$ & 42 \\
Standard deviation & 18 & - & - & - & 5 \\
\hline
\end{tabular}

\subsubsection{Quality Test for the Ziguinchor Region}

Ziguinchor has an average nut count of $227 \pm 36$ nuts $/ \mathrm{kg}$, with a defect rate of $7 \%$ (Table 6). The kernel yield is $25 \%$ with a KOR of $45( \pm 6)$. The measured humidity is $8.2 \%$.

The quality can be classified as appreciable. Nevertheless, the best kernel yield is noted in the Ziguinchor region. This means that larger nuts count are not always the best. The quality of the nuts is good in all links (KOR which varies between 41-51 lbs and kernel yield rate of 23-29\%).

Table 6. Assessment of nut quality for Ziguinchor region.

\begin{tabular}{llllll}
\hline & NC & DR & UK & KY & KOR \\
\hline Sample 1 & 189 & 5 & 280 & $29,1 \%$ & 51 \\
Sample 2 & 261 & 10 & 187 & $23,8 \%$ & 42 \\
Sample 3 & 232 & 6 & 246 & $23,3 \%$ & 41 \\
Average & 227 & 7 & 238 & $25,4 \%$ & 45 \\
Standard deviation & 36 & - & - & - & 6 \\
\hline
\end{tabular}

\subsection{Indicators Country of Nuts}

The cashew production in Senegal is between 20,000-25,000 tonnes per year (Table 7). On average, households in Senegal that grow cashew nuts dedicate 2-3 ha to the crop The yield per household is $728 \mathrm{~kg}$ compared to 297 $\mathrm{kg}$ per ha. The most important quality indicators (KOR and KY) are $42-51 \mathrm{lbs}$ and $24 \%$ respectively. In the study area, the standard on variables (KOR, Useful Kernel, Defect Rate and Moisture) is consistent with international standards. The KOR is 42-51 versus 49-50, which is applied by some exporters and 
is considered as a "good quality" grade. Kernel yield is $24 \%$ compared to $22 \%$ applied by the industry. The only variable that is not at the maximum of the standard is nut count with 193 grains per kilogram versus 180 grains per kilogram applied by some exporters-industrials.

Table 7. Parameters of cashew nut production in Senegal.

\begin{tabular}{ll}
\hline Parameters & Data collected \\
\hline Area per household (ha) & $2-3$ \\
Production (tonnes) & $20000-25000$ \\
Yield (Kg/household) & 728 \\
Yield/Ha (kg/ha) & 297 \\
Average KOR (lbs) & $42 \pm 9$ \\
Average Nut Count (grains/kg) & $193 \pm 40$ \\
Kernel Yield (KY) (\%) & $24 \pm 4$ \\
Defective rate Kernel (\%) & $10 \pm 3$ \\
\hline
\end{tabular}

\subsection{Eigenvalue of Inertia}

The PCA analysis showed that axis 1 contains $59 \%$ of the information while axis 2 explained $18 \%$ of the total variability, i.e. a total of $77 \%$ of the information is in the components (1 and 2) (Table 8).

Table 8. Key Components/Correlation.

\begin{tabular}{lllll}
\hline Comp & Ev & Diff & Pro & Cumul \\
\hline Comp1 & 2.95244 & 2.0543 & 0.5905 & 0.5905 \\
Comp2 & .898141 & .172247 & 0.1796 & 0.7701 \\
Comp3 & .725894 & .30262 & 0.1452 & 0.9153 \\
Comp4 & .423273 & .423022 & 0.0847 & 0.9999 \\
Comp5 & .000250879 &. & 0.0001 & 1.0000 \\
\hline
\end{tabular}

Comp $=$ Components, Ev= Eigenvalue, Diff=difference, Pro= Proportion, Cumul= Cumulative

The cartel elbow rule was applied for the choice of factor axes. The bend is drawn after the second axis. Thus, the first two dimensions were retained with confirmation that $77 \%$ of the information was retrieved.

\subsection{Results for Individuals}

The results in Figure 7 show a strong correlation between KOR and Kernel Yield (KY). The higher the KOR (a positive) the higher the Kernel yield. On the other hand, nut moisture (zHumidity) and Nut Count (zCN) are negatively correlated.

The moisture content does not depend on the number of nuts obtained per $\mathrm{kg}$ or per bag. The higher the moisture content $(>10 \%)$, the higher the risk of defect. Defect rate (zDR), KOR (zKOR) and Kernel Yield (zKY) are also negatively related. This shows that the higher the default rate $(>$ $24 \%$ ), the poorer the production tends to be on the KY and KOR parameters. These variables (KOR and KY) are very important in measuring the quality of the nuts for the processing link.

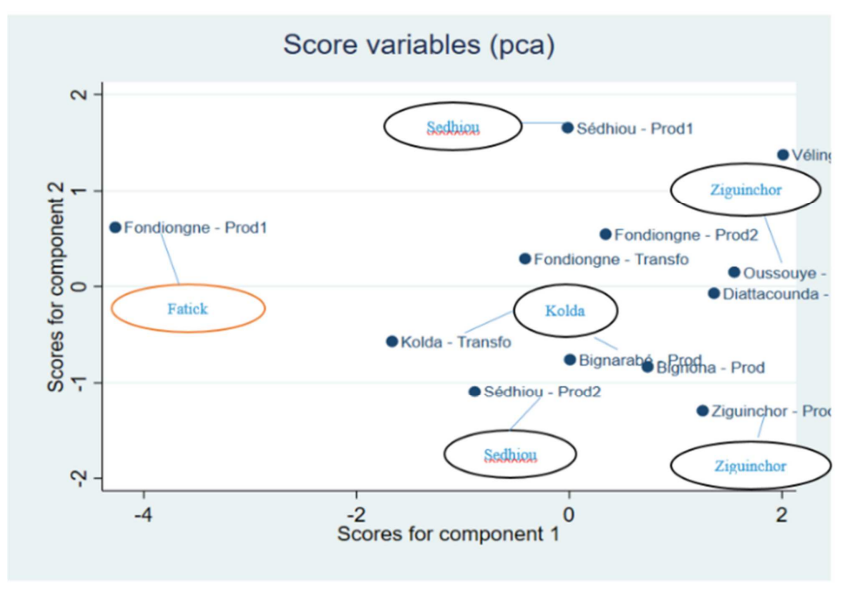

Figure 6. Variable diagram.

\subsection{Variable Results}

The quality of raw cashew nuts from the Sedhiou and Ziguinchor regions are very similar (Group 1) (Figure 6). This similarity is valid for nuts from the Ziguinchor and Kolda regions (Group 2).

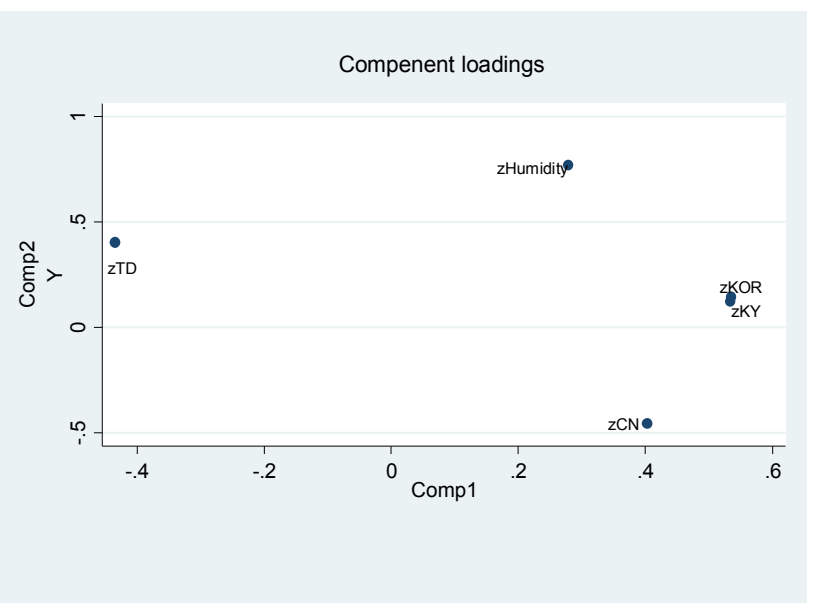

Figure 7. Individus diagram.

On the other hand, for the Fatick region, the quality characteristics (Nut count, KOR, moisture content, Kernel yield, and defect rate) of the nuts are strongly differ from those of the Casamance (Group 3).

The quality characteristics on the Group 1 label are nuts from the processors. Those on the Group 2 label are nuts from producers.

Thus, the analysis shows that processors in all the regions concerned buy generally good quality nuts (high KOR and Kernel yield), with an average of $42( \pm 7)$ and $24 \%$ respectively. The moisture content is $8 \%$. The nut counts is at $193( \pm 40)$ nuts per kg.

\section{Discussions}

\subsection{Comparison of Quality Raw}

Analysis of the yield quality based on the ACA method 
showed that very good nuts influence the quality of the Kernel Yield (KY) obtained after processing $[3,11,21]$. The average $\mathrm{KOR}$ is $42 \pm 9 \mathrm{lbs}$ depending on the origin. This average masks the inter-regional variations. The highest KOR was recorded in the Ziguinchor region $(45 \pm 6 \mathrm{lbs})$ while the lowest was noted in the Fatick region $(38 \pm 9 \mathrm{lbs})$. This variation in KOR is correlated with other variables such as kernel yield or the amount of useful kernel, moisture content, and nut defect. The largest nuts were recorded in the Fatick region (145 nuts $/ \mathrm{kg} \pm 16.1$ ) while the Ziguinchor region had the smallest nuts $(227$ nuts $/ \mathrm{kg} \pm 36)$ with a moisture content of $8 \%$. A moisture content of 8 to $10 \%$ is generally acceptable as it is safe for cashew nuts and most edible almonds and oilseeds [21]. The fundamental consideration is that a quality cashew nut is due to the combination of large nut sizes (low nut count per kilo) and a high percentage of kernel inside the shell (high yield) [25]. This supports our findings that quality measurement requires composite indicators, the most important of which are KOR and KY. KOR as a criterion is very important in determining quality export in the cashew nut trade. Indeed, the Cashew nut with a KOR $\geq 46 \mathrm{lbs}$ allows sellers to attract the premium price and to produce good quality grains during processing. According also to [7], the KOR of cashew nuts from producing countries varies from 40 to $56 \mathrm{lbs}$ per $80 \mathrm{~kg}$, giving a better quality of kernel.

The PCA test shows that southern regions have similar parameters for nut quality. In contrast, the Fatick region has different parameters from the other three regions. These differences can be related to soil quality, plant material, and the rainfall pattern noted between the two agro-ecological zone. The highest Kernel Yield (25\%) is noted in the sample of nuts from processors in the Ziguinchor and Fatick regions while the lowest KY are noted among producers.

In general, quality controls in the regions are done by exporters, collectors, and processors. Producers do not have the specialized knowledge or culture to do KOR testing. However, the exercise of counting nuts per kilogram is done by some producers. Nut Count is also used to assess quality. In Senegal many studies have been carried out on dendrometric characterization of nuts ([9-19]). According to [3] larger nuts are easier to process and are preferred by consumers. Indeed, the combination of large cashews with a high percentage of kernels generates the highest price. According to [10], product quality influences the demand for those products on the world market, which, in turn, positively affects the price based on the quality of raw cashew nuts. These elements explain the choice of Senegal by exporters.

\subsection{Quality of Nuts in Senegal}

This study was conducted in an area which covers almost $90 \%$ of Senegal's cashew production. According this survey, the production is estimated at 20,000 to 25,000 tonnes/year. The quality of nuts in the four major producing zones demonstrates the high quality of Senegalese nuts. The average over the whole sample is 42 to $51 \mathrm{lbs}$ per $80 \mathrm{~kg}$ lot, revealing good quality compared to international standards which vary from 40 to $50 \mathrm{lbs}$ per $80 \mathrm{~kg}$ lot in Benin [14]. These results corroborate those of the IRD/ISRA [15] report on cashew nut varieties. Based on their study, Senegal, Gambia and Guinea Bissau have the best KOR (up to $50 \mathrm{lbs}$ ) compared to other West African countries. However, in the same report, the distribution of KORs by region is slightly different to our results.

The percentage of defective nuts is between $10 \%$ against $24 \%$ according to [14]. The average nut count for the whole is 193 nuts $/ \mathrm{kg}$, which is in line with international standards varying between 150 and 240 nuts/kg [14]. Similar results were found by [21] in his study.

The average moisture content is $8 \%$, meeting the standards [3-4] required for efficient processing operations according to a 2017 report of the Ministry of Commerce, Industry and Handicrafts Burkina-Faso. This level of quality of the Senegalese kernel (judged as good) can be maintained or improved. For this, constraints related to diseases and soil fertilization must be properly taken into account by producers [5]. According to PADEC/IRD surveys [25], 59\% of households noted diseases and more than $56.17 \%$ reported the presence of pests in the same area targeted by the study (Kolda, Sedhiou, Ziguinchor and Fatick). Thus, according to [21], pests and diseases play an important role in determining the quality of nuts since they can cause premature nut drop, incomplete filling of the nuts, and damage to the nut. The management of pests and diseases requires a strategic response, making joint actions between different actors in the value chain particularly necessary [29]. Senegal will improve its quality if control methods are deployed against these pests.

\section{Conclusion}

This study evaluated the quality of nuts in the four major producing regions of Senegal (Kolda, Sedhiou, Ziguinchor and Fatick). The study area, which accounts for $90 \%$ of national production, estimated at 20,000 to 25,000 tonnes, has good nut quality. The average KOR is $42 \pm 9 \mathrm{lbs}$ with a kernel weight of 193 nuts per kilogram. The defect rate is $10 \%$ with an average moisture content of $8 \%$ in all regions. Kernel yield is $24 \%$. All these parameters meet the international standards required for the processing of the nut. These elements also showed that the choice of exporters (Indian, Chinese) on Senegal is not fortuitous. Even if annual production remains low (less than $1 \%$ of world production), the quality of the nuts makes the difference. If we consider almond product in Senegal, the quality of the raw nuts has a positive impact on the quantity of "all grades" kernels that can be obtained from shelling, but it also has an impact on the proportions of whole white almonds obtained and income of the workers who are paid according to the yield of whole kernel. Therefore, it is a central issue for the profitability of processing and the income of the workers in the sector. In the light of the results obtained, it is necessary to consolidate the quality of the cashew nut and add value to the kernel through processing, which offers more income and creates more jobs locally in Senegal. 


\section{Conflicts of Interest}

The authors declare that they have no competing interests.

\section{Acknowledgements}

The authors gratefully acknowledged the Programme d'Appui au Développement Economique de la Casamance (PADEC), the Institut Senegalais de Recherches Agricoles (ISRA), the Cheikh Anta Diop (UCAD) university, Kelsey Dudziak and all the cashew nut producers of Casamance and Sine Saloum (Fatick) (Senegal).

\section{References}

[1] ACA. (2011). African Cashew Alliance, Annual Report 2011. Accra, Ghana, ACA, 16 p.

[2] Agence Nationale de la Statistique et Démographie (ANSD). (2017 a). Résumé Rapport Deuxième enquête de suivi de la pauvreté au Sénégal (ESPS), 11 p, récupéré de: anads.ansd.sn/index.php/citations/3

[3] Anato FM, Sinzogan AAC, Offenberg J, Abandonon A, Wargui R, Deguenon JM, Ayelo PM, Vayssières JF, Kossou D. (2017). Oecophylla longinoda (Hymenoptera: Formicidae) Lead to Increased Cashew Kernel Size and Kernel Quality. Journal of Economic Entomology, 110 (3): 1133-1137. DOI: http://dx.doi.org/10.1093/jee/tox054

[4] Azam-Ali S H. and Judge, E C. (2001) "Small-Scale cashew nut processing", Schumacher Centre for Technology \& Development, Bourton Dunsmore, Rugby, Wickshire, CV39QZ, UK.

[5] Balasubramanian, D. (2006). Improving whole kernel recovery in cashew nut processing. Agricultural Mechanisation in Asia Africa and Latin America, 37 (1): 58-64.

https://www.researchgate.net/publication/279546143

[6] Coly ML. (2016). Etudes des caractéristiques morphologiques et de la germination des noix d'Anacardium occidentale L. de la région de Ziguinchor. Mémoire de Fin de cycle Master: Ecole Nationale Supérieur d'Agriculture (Sénégal), 57 p.

[7] Dahiya, S. (2010). Cashew Processors Training Program: Ouality Assessment and Harvest /Post Harvest handling. Ibadan, Nigerian. African Cashew Alliance http://www.agoatoolkit.com/agoa/English/Select\%20Prod ucts/Cashews/Cashew\%20sector\%20Development $\% 20 \mathrm{Co}$ untry\%20Study/04.pdf

[8] Dervin C. (1988). Comment interpréter les résultats d'une analyse factorielle des correspondances? STATITCF, $75 \mathrm{p}$.

[9] Diédhiou B. (2017). Morphologie et germination comparées des semences de quatre morphotypes d'Anacardium occidentale L. au Sénégal. Mémoire de Fin de cycle: Institut Supérieur de Formation Agricole et Rurale (Sénégal), 61.

[10] Fitzpatrick, J. (2010). "Quality characteristics of Cashew nut" A survey compiled for CBI; http; //www.CBI.eu/disclaimer
[11] Gilleo J, Kebba Jassey, K, Yeager Sallah, J. (2011). Cashew Business Basics: The Gambia River Basin Cashew Value Chain Enhancement Project (CEP), International Relief and Development (IRD), récupéré de $\mathrm{http}: / /$ www.africancashewalliance.com/sites/default/files/docu ments/Cashew_12Oct2011.pdf

[12] Hassine, N. B. et Matoussi M. S. (2006). Compétitivité et qualité des produits: Le cas de l'agriculture et de l'agroalimentaire. $36 \mathrm{p}$.

[13] INADA, (2012). Situation de la filière anacarde dans le Balantacounda. Casamance/Sénégal, INADA vol 1, 20 p.

[14] Initiative de Cajou Africain (ICA): (2011). Fiche de Résultats $n^{\circ}$ 003/201, Bénin, récupéré de www.comcashew.org/imglib/downloads/270711_Benin_\%20 Cartographie\%20KOR\%202011.pdf. 2 p.

[15] IRD/ISRA (2013). Caractérisation des variétés d'anacarde au Sénégal et en Gambie. 11 p.

[16] Martin PJ, Topper CP, Bashiru RA, Boma F, Waal DD, Harries HH, Kasuga LJ, Katanila N, Kikoka LP, Lamboll R, Maddison AC, Majule AE, Masawe PA, Millanzi KJ, Nathaniels NQ, Shomari SH, Sijaona ME, Stathers T. (1997). Cashew nut production in Tanzania: Constraints and progress through integrated crop management. Journal Crop Protection Vol. 16 No. P 5-14. PII: SO261-2194 (96) 00067-1.

[17] Mbodj. S (2019). Les effets des arbres sur la sécurité alimentaire des ménages ruraux des zones de Niakhar et de Nioro. Mémoire pour l'obtention du diplôme d'Ingénieur des travaux statistiques, $87 \mathrm{p}$.

[18] Millago ADM (2014). Etudes des caractéristiques morphologiques et de la viabilité des semences de Parkia Biglobosa (jacq.) r. br. ex g. don. - germoplasme de conservation à long terme à $4^{\circ} \mathrm{c}$. Mémoire de master de fin cycle IRD de Bobo Diolassou/Burkina Faso. 61 p.

[19] Ndiaye L. (2019). Identification et caractérisation des différentes variétés d'anacardiers (Anacardium Occidentale L.) Cultivées dans le Balantacounda (Sénégal). Mémoire de Master Agroforesterie, Ecologie, Adaptation, 65 p.

[20] Niang, PM., (2016). Caractérisation de noix et tests de germination de six variétés d'Anacardium occidentale $\mathrm{L}$. de la région de Sédhiou, Mémoire de Master: Université de Thiès (Sénégal), $50 \mathrm{p}$.

[21] Ogunsina, BS. (2013). Crackability and chemical composition of pre-treated cashew nuts using a hand-operated knife cutter. Agric Eng Int: CIGR Journal, 15 (2): 275-283. DOI: www.cigrjournal.org.

[22] Ogunwolu S. O, Yahaya L. E, Mokwunye F. C., Ogunjobi M. A. K., and Olalekan-Adeniran M. A. (2016). "Evaluation of Quality of Raw Cashew (Anacardium occidentale, L) Nut from Major Cashew Producing Areas of Nigeria." American Journal of Food Science and Technology, vol. 4, no. 6 (2016): 178-181. doi: 10.12691/ajfst-4-6-4

[23] Pal S. (2016). Compétitivité mondiale: Données de référence sur l'industrie mondiale de transformation du cajou. Festival et Expo mondiaux 2016 sur le cajou organisés par l'ACA. Guinea-Bissau, 19- 22 septembre 2016. 15 pJ. Clerk Maxwell, A Treatise on Electricity and Magnetism, 3rd ed., vol. 2. Oxford: Clarendon, 1892, pp. 68-73. 
[24] Planetoscope. 2019. Statistiques Mondiales de l'anacarde, récupéré de

https://www.planetoscope.com/Epices/1253-production-de-no ix-de-cajou-dans-le-monde.html

[25] Programme d'Appui au Développement Economique de la Casamance (PADEC) \& International Relief and Development (IRD). (2014). Rapport des enquêtes socio-économiques sur la filière anacarde au Sénégal, $210 \mathrm{p}$.

[26] Réseau des ONG Européennes d'Appui au Développement (RONGEAD). (2015). Etude du marché de l'anacarde au Mali et en Afrique de l'Ouest. Rapport du projet de Commercialisation et Transformation de l'Anacarde dans la Région de Sikasso», financé par la Coopération Espagnole et mis en œuvre par TRAGSA et le Ministère de l'Agriculture de la République du Mali. $66 \mathrm{p}$.

[27] Samb C, Touré M, Faye E, Ba H, Diallo A, Badiane S, Sanogo
D. (2018). «Caractéristiques sociodémographique, structurale et agronomique des plantations d'anacardier (Anacardium occidentale L.) du Bassin arachidier et de la Casamance / Sénégal». Journal of Animal and Plant Sciences 38 (3): 6307-6325. http://www.m.elewa.org/JAPS

[28] Sarr M. (2002) « Analyse du secteur de l'anacarde au Sénégal, situation actuelle et perspective de développement", Projet de rapport de synthèse, $44 \mathrm{p}$.

[29] Silva M., Pereira S. C. F., and Gold S. (2018). The response of the Brazilian cashew nut supply chain to natural disasters: A practice-based view. Journal of cleaner production. 204 (2018) 660-671. DOI: https://doi.org/10.1016/j.jclepro.2018.08.340

[30] United States Agency for International Development (USAID). (2006) «La chaine de valeur Anacarde au Sénégal: Analyse et cadre stratégique d'initiative pour la croissance de la filière», 77. p. 